\title{
Kelentingan Penghidupan Rumah Tangga Eks Buruh Harian Lepas Perkebunan Kelapa Sawit di Desa Sei Mangkei
}

\author{
Ringgo Arman* \\ Hariyadi** \\ Setyawan Sunito*** \\ *Program Studi Pengelolaan Sumberdaya Alam dan Lingkungan IPB \\ ** Departemen Agronomi dan Hortikultura, Fakultas Pertanian IPB \\ ** Departemen Sains Komunikasi dan Pengembangan Masyarakat, FEM IPB
}

\begin{abstract}
Abstrak
Areal perkebunan kelapa sawit PTPN III (Persero) Afdeling I telah berubah menjadi Kawasan Ekonomi Khusus Sei Mangkei (SEZ), hal ini menimbulkan dampak penting bagi masalah mendasar yang memisahkan penghidupan rumah tangga Buruh Harian Lepas (BHL) perkebunan kelapa sawit di Desa Sei Mangkei. Penelitian ini mengilustrasikan ketahanan penghidupan rumah tangga BHL di Desa Sei Mangkei. Penelitian ini bertujuan untuk mengukur ketahanan masyarakat terhadap suatu lanskap yang berubah afdeling I PTPN III (Persero) untuk membagi Sei Mangkei KEK. Analisis ketahanan penghidupan menggunakan konsep peraturan yang disebut indeks, indikator ketahanan dan ketahanan rumah tangga kemudian dikumpulkan melalui kuesioner. Respondennya sebanyak 30 rumah tangga BHL, sampelnya berada di Desa Sei Mangkei. Dari hasil perhitungan indeks diperoleh bahwa hasil indeks ketahanan pangan rumah tangga sebesar 0,35 . Itu berarti ketahanan hidup rumah tangga BHL rendah bila terjadi perubahan lansekap saat bertanding. Saya membagi Sei Mangkei SEZ
\end{abstract}

Kata kunci: Kawasan Ekonomi Khusus, Desa Sei Mangkei, pekerja perkebunan kelapa sawit (BHL) kelapa sawit, ketahanan hidup.

\begin{abstract}
The landscape changed of palm oil plantation PTPN III (Persero) Afdeling I became The Sei Mangkei Special Economic Zone (SEZ), it gaves essential impact to the basic problems divided the households livelihood of casual workers (BHL) palm oil plantation in the Sei Mangkei village. This study was illustrated the resilience of the BHL households livelihood in the Sei Mangkei village. This paper aims to measured community resilience of a landscape changed afdeling I PTPN III (Persero) to divided Sei Mangkei SEZ. Analysis of livelihood resilience used a concept of rules is called an index, resilience indicators and households resilience were then collected through questionnaires. The respondent are many 30 BHL households, the sampling located at Sei Mangkei Village. From the calculation of the index has been obtained that result households resilience index a value of 0,35. That means livelihood resilience of BHL household is low when there has been a landscape change at afdeling I divided Sei Mangkei SEZ
\end{abstract}

Keywords: Special Economic Zones, Sei Mangkei Village, Casual worker (BHL) palm oil plantation, livelihood resilience. 


\section{PENDAHULUAN}

Nagori (Desa) Sei Mangkei wilayah administrasinya mencakup Afdeling I PTPN III. Desa Sei Mangkei memiliki 6 huta(dusun) dari keenam dusun tersebut, empat diantaranya merupakan emplasemen Afdeling I PTPN III. Desa Sei Mangkei awalnya adalah tanah absentee dari perkebunan dijaman kolonial Belanda seluas kuranglebih 25 ha yang kemudian berubah status menjadi desa ditahun 1960-an. Warga Desa Sei Mangkei mayoritas adalah etnik Jawa yang merupakan generasi dari buruh-buruh perkebunan jaman kolonial Belanda. Sebagai desa dengan kultur perkebunan, penghidupan (livelihood) warga Desa Sei Mangkei dipengaruhi oleh aktivitas perkebunan kelapa sawit PTPN III.

Kawasan Ekonomi Khusus (KEK) Sei Mangkei yang ditetapkan berdasarkan Peraturan Pemerintah Republik Indonesia Nomor 29 Tahun 2012 yang merupakan bagian dari Masterplan Percepatan dan Perluasan Pembangunan Ekonomi Indonesia (MP3EI) yang dilegalkan dengan Perpres No. 32 Tahun 2011 (Buhaerah at al, 2014). KEK Sei Mangkei dikembangkan diatas lahan seluas 2.002,77 ha merupakan lahan PT. Perkebunan Nusantara III (PTPN III) yang terletak dalam wilayah Desa Sei Mangkei, Kecamatan Bosar Maligas, Kabupaten Simalungun, Provinsi Sumatra Utara, diatas lahan seluas 2.002,77 ha. Perubahan lanskap menurut Peterson et.al (2013) dapatmempengaruhi aktivitas-aktivitas ekonomi masyarakat, sedangkan Dai et.al (2013) menggambarkan adanya perubahan berbagai lapangan pekerjaan petani ketika suatu kawasan pertanian berubah menjadi kawasan industri serta perubahan penghidupan masyarakat sekitar kawasan tersebut dan terjadi pula pergeseran kemampuan masyarakatnya.

Kelompok masyarakat yang rentan terhadap perubahan lanskap Afdeling I PTPN IIIdari perkebunan kelapa sawit menjadi kawasan industri adalah rumahtangga Buruh Harian Lepas (BHL). BHL perkebunan kelapa sawit umumnya bekerja sebagai tenaga panen dan perawatan, setelah lahan afdeling I berubah fungsi menjadi KEK Sei Mangkai, pada tahun 2014 tidak adalagi aktivitas perawatan tegakan sawit dilahan tersebut. Dengan demikian tenaga BHL tidak lagi dibutuhkan. Dalam pandangan para ahli dari Institute Development Studies, sistem penghidupan masyarakatDesa Sei Mangkei yang mengalami berubahan ini dapat dikatakan sustainable (berkelanjutan) jika sistem penghidupan tersebut memiliki kemampuan dalam coping (mengatasi) serta memulihkan kembali keadaan atas stresses (tekanantekanan) dan shocks (goncangangoncangan) yang dihadapi (Scoones 1998). Lebih lanjut menurut Scoones, dalam menghadapi gangguan sistem penghidupan tersebut dengan memanfaatkan capitals (modal-modal) penghidupannya, modal-modal tersebut adalah natural capital (modal alam), economic/financial capital (modal ekonomi/keuangan), human capital (modal manusia) dan social capital (modal sosial). Dengan memanfaatkan livelihood capitals (modal-modal 
penghidupan) yang dimiliki dan atau yang dapat diakses merupakan buffer capacity (penyokong) yang dapat mempengaruhi resilience(kelentingan) sistem penghidupannya. Buffer capacitymenurut Speranza (2014)adalah kemampuan sistem penghidupan dalam menjalani (menyerap) tekanan-tekan atau goncangan-goncangan dan masih mempertahankan sistem penghidupannya. Kelentinganmenurut Holling (1973) digambarkan sebagai kemampuan dari suatu sistem dalam menyerap faktor-faktor yang menyebabkan perubahan serta ukuranukuran yang dapat membuat sistem tersebut bertahan serta kemampuan menggunakan segala yang dimilikinya untuk kembali kekeadaan kesetimbangan setelah menghadapi perubahan-perubahan, sedangkan menurut Adger (2000) kelentingan dapat meningkatkan kemampuan untuk mengatasi tekanan dan guncangan oleh sebab itu, kelentingan dapat mengurangi livelihoodvulnerability(kerentanan

penghidupan), menurut Gil (2017) kelentingan merupakan fenomena yang lahir dari pilihan sadar dalam interaksi antara agen, sistem pertanian, asset fisik, sosial, ekonomi, kelembagaa serta lingkungan dalam upaya melawan gangguan-gangguan yang terjadi pada sistem penghidupannya.Dalam penelitian ini kami menganalisis kelentingan penghidupan eks rumahtangga buruh harian lepas (BHL) perkebunan sawit di Desa Sei Mangkei pasca perubahan lanskap perkebunan kelapa sawit sawit Afdeling I PTPN III menjadi Kawasan Ekonomi Khusus (KEK) Sei Mangkei.

\section{METODE PENELITIAN}

Unit Analisis dan Sampel

Unit analisis data yang digunakan dalam penelitian ini adalah rumahtangga eks buruh harian lepas (BHL) perkebunan sawit Afdeling I di Nagori Sei Mangkei di Desa Sei Mangkei. Metode penarikan sampel pada penelitian ini menggunakan purposive sampling, jumlah sampel yang diambil sebanyak 30 responden. Teknik penarikan sampel pusposif menurut Guarte (2006) penentuannya secara subjektif oleh peneliti tanpa menggunakan desain praanggapan untuk penentuan varian penilaian.Lebih lanjut menurut Guarte, dalam menggunakan analisis statistik deskriptif pada penelitian sosial,purposive samplingbanyak digunakan.Teknik pengumpulan data melalui wawancara terstruktur dengan bantuan kuesioner dan in depth interview. Pengumpulan data dilakukan pada September - Nopember 2016.

\section{Kerangka Penilaian Indeks Kelentingan Penghidupan (Livelihood Resilence Index)}

Pendekatan indeks pada penelitian ini menggunakan pendekatan rata-rata bobot setimbangan seperti yang digunakan oleh Sullivan (2002). Karena setiap sub komponen diukur pada skala yang berbada maka perlu distandarisasi (Hahn at all 2009), dengan persamaan sebagai berikut:

$s_{h}=\frac{s_{d}-s_{\min }}{s_{\max }-s_{\min }}$

Dimana: $S_{h}$ adalah data rata-rata \% subkomponen yang diperoleh.

$S_{\text {min, }} S_{\text {max }}$ adalah nilai maksimum dan minimum dari masing-masing subkomponen (minimum $0 \%$, maksimum 100\%). 
Komponen utama diindeks dengan persamaan:

$M_{h}=\frac{\sum_{i=1}^{n} \text { indeks } S h_{i}}{n}$

Dimana: $\mathrm{M}_{\mathrm{h}}$ adalah satu dari lima komponen utama,indeks $S h_{i}$ mewakili sub-komponen yang diideks oleh $i$ yang merupakan bagian-bagian yang menyusun penilaian komponen utama, $n$ adalah jumlah sub komponen dari masing-masing komponen utama.

Setelah nilai dari 5 komponen utama diperoleh (komponen utama, sub komponen dan indikator seperti pada Tabel. 1.) maka indeks kelentingan penghidupan dihitung dengan persamaan:

indeks kelentingan $=\frac{\sum_{i=1}^{n=5} w_{M i} M_{h i}}{\sum_{i=1}^{n=5} w_{M i}} \ldots . .$.

Dimana: WMi adalah bobot masing masing komponen utama dan $\mathrm{M}_{\mathrm{h}}$ i adalah nilai masing-masing komponen utama.

Tabel. 1. Komponen Utama, Sub Komponen dan Indikator Penilaian Indeks Kelentingan Penghidupan eks Rumahtangga Buruh Harian Lepas di Desa Sei Mangkei

\begin{tabular}{|c|c|c|}
\hline $\begin{array}{c}\text { Komponen } \\
\text { Utama } \\
\text { (livelihood } \\
\text { capitals) }\end{array}$ & Sub Komponen & Indikator \\
\hline \multirow[t]{2}{*}{ Modal Alam } & Kepemilikan Ternak & \% rumahtangga yang memiliki ternak \\
\hline & Lahan Garapan & $\%$ rumahtangga yang memiliki akses lahan garpan \\
\hline \multirow{6}{*}{$\begin{array}{l}\text { Modal } \\
\text { Finansial }\end{array}$} & Sumber Pendapatan & \% sumber nafkah dari KK \\
\hline & & \% sumber nafkah dari KK dan anggota keluarga lain \\
\hline & Tabungan & \% KK yang menabung sebagian pendapatan \\
\hline & $\begin{array}{l}\text { Stabilitas } \\
\text { Pendapatan }\end{array}$ & \% rumahtangga memiliki akses pinjaman bank \\
\hline & & $\%$ rumahtangga yang meminjam dari keluarga \\
\hline & & $\begin{array}{l}\% \text { rumahtangga yang meminjam dari } \\
\text { tetangga/warung }\end{array}$ \\
\hline \multirow[t]{4}{*}{ Modal Manusia } & $\begin{array}{l}\text { Pendidikan dan } \\
\text { Ketrampilan }\end{array}$ & \% KK yang berpendidikan SMP\& SMA \\
\hline & & \% KK yang berpendidikan SD \\
\hline & & \% KK yang memiliki kemampuan pertukangan \\
\hline & Usia Produktif & \% KK dalam usia produktif \\
\hline \multirow[t]{4}{*}{ Modal Fisik } & Pemilikan Aset & $\%$ rumahtangga yang memilik rumah sendiri \\
\hline & & $\%$ rumahtangga yang memilik kendaraan roda dua \\
\hline & Pemanfaatan Aset & $\%$ rumahtangga yang mengontrakan rumahnya \\
\hline & & $\%$ rumahtangga yang mengojekkan kendaraannya \\
\hline \multirow[t]{5}{*}{ Modal Sosial } & Jaringan Sosial & $\begin{array}{l}\text { \% suami dan istri merupakan penduduk asli desa } \\
\% \text { keluarga pendatang }\end{array}$ \\
\hline & $\begin{array}{l}\text { Jaringan pengaman } \\
\text { sosial }\end{array}$ & $\%$ rumahtangga yang mengikuti arisan \\
\hline & & $\%$ rumahtangga yang mengikuti progran PNPM \\
\hline & & $\%$ rumahtangga yang mendapat beras raskin \\
\hline & & $\begin{array}{l}\% \text { rumahtanggayang mendapat program CSR PT. } \\
\text { PN III }\end{array}$ \\
\hline
\end{tabular}




\section{HASIL DAN PEMBAHASAN}

Skala untuk mengukur kelentingan pada penelitian ini berada antara 0 sampai dengan 1, maka untuk menginterpretasi indeks kelentingnan dari hasil perhitungan adalah jika nilai mendekati 1 menunjukan paling tinggi kelentingannya mendekati 0 rendah sementara 0,5 adalah menengah (Qasim et al 2016). Hasil pengindeksan modal-modal penghidupan rumahtangga eks buruh perkebunan kelapa sawit Afdeling I diperoleh indeks kelentingan penghidupan sebesar 0,35 dari angka indeks ini maka dapat dikatakan bahwa dengan adanya perubahan lanskap perkebunan kelapa sawit afdeling I keluarga eks buruh harian lepas tersebut memiliki kelentingan rendah, seperti disajikan pada Tabel. 2 .

Tabel. 2. Indeks Komponen Utama, Sub komponen dan Kelentingan

\begin{tabular}{|c|c|c|c|c|}
\hline $\begin{array}{l}\text { Komponen Utama } \\
\text { (livelihood capitals) }\end{array}$ & Indeks & Subkomponen & Indeks & $\begin{array}{l}\text { Indeks } \\
\text { kelentingan }\end{array}$ \\
\hline \multirow{2}{*}{ Modal alam } & \multirow{2}{*}{0,08} & Kepemilikan Ternak & 0,17 & \multirow{11}{*}{0,35} \\
\hline & & Lahan Garapan & 0,00 & \\
\hline \multirow{3}{*}{ Modal finansial } & \multirow{3}{*}{0,32} & Sumber Pendapatan & 0,50 & \\
\hline & & Tabungan & 0,13 & \\
\hline & & Stabilitas Pendapatan & 0,33 & \\
\hline \multirow{2}{*}{ Modal manusia } & \multirow{2}{*}{0,48} & Pendidikan dan Ketrampilan & 0,37 & \\
\hline & & Usia Produktif & 0,60 & \\
\hline \multirow{2}{*}{ Modal fisik } & \multirow{2}{*}{0,48} & Pemilikan Aset & 0,78 & \\
\hline & & Pemanfaatan Aset & 0,17 & \\
\hline \multirow{2}{*}{ Modal sosial } & \multirow{2}{*}{0,40} & Jaringan Sosial & 0,33 & \\
\hline & & Jaringan pengaman sosial & 0,47 & \\
\hline
\end{tabular}

\section{Modal Alam}

Indikator yang digunakan untuk menilai kepemilikan dan akses atas modal alam adalah kepemilikan ternak $(17,14 \%)$ dan lahan garapan (0\%). Kepemilikan ternak dalam hal ini adalah ternak sapi dan/atau kambing yang dimiliki responden. Kepemilikan ternak pada penelitian ini dari hasil wawancara mendalam dapat menjadi penyokong penghidupan keluarga eks BHL dimana ternak yang dimiliki dapat dijual ketika keluarga membutuhkan dana dalam keadaan-keadaan mendesak. Sedangkan akses kelahan garapan seluruh responden tidak memiliki lahan garapan. Dalam masyarakat pedesaan akses ke lahan adalah hal yang mendasar sebagai modal penghidupan Quan (2001), sementara Etim at all (2013) menghubungkan kejadian kemiskinan ketiadaan akses lahan. Pada penelitian ini akses rumahtangga eks BHL terhadap lahan dalam menyokong penghidupan rumahtangganya hanya di lahan perkebunan kelapa sawit sebagai BHL, maka perubahan lanskap afdeling I menjadi KEK Sei Mangkei secara langsung mempengaruhi sistem penghidupan keluarga eks BHL di Desa Sei Mangkei.

\section{Modal Finansial}

Modal finansial dinilai atas 3 subkomponen yaitu sumber pendapatan 
dengan indikator sumber pendapatan dari kepala keluarga (87\%) dan sumber dari kepala keluarga dan anggota keluarga lain (13\%). Disini terlihat bahwa sumbernafkah rumahtangga eks BHL terbesar dari aktivitas kepala keluarga. Dari hasil wawancara mendalam diketahui bahwa saat rumahtangga eks BHL ini masih memiliki akses ke perkebunan kelapa sawit, sumber nafkah selain dari kepala keluarga juga dari aktivitas istri maupun anggota keluarga lain yang juga sebagai BHL. Subkomponen tabungan dengan indikatorrumahtangga yang menabung sebagian pendapatan (13\%). Sub komponen stabilitas pendapatan dengan indikator yang meminjam dari keluarga dekat (63\%), meminjam di tetangga atau warung $(37 \%)$ dan mengakses perbankan $(0 \%)$. Pada sub komponen stabilitas pendapatan ini tergambar bahwa disaat keluarga eks BHL dalam mengatasi kebutuhan finansial yang mendesak, mereka memanfaatkan relasi sosial seperti meminjam dari keluarga atau tetangga, hal ini juga menggambarkan solidaritas yang masih kuat dalam satu komunitas (Gunawan, dan Sugiyanto, 2017), jaringan kekerabatan yang kuat pada komunitas dapat meningkatkan kapasitas adaptif yang dapat mengurangi stress(tekanantekanan) pada sistem penghidupan (Panjaitan et all 2017). Seluruh responden pada penelitian ini tidak ada yang mengkases pinjaman bank.

\section{Modal Manusia}

Sub komponen modal manusia pada penelitian ini adalah usia produktif dengan indikator kepala keluarga yang berusia produktif $(60 \%)$, sub komponen pendidikan dan ketrampilan dengan kriteria kepala keluarga berpendidikan SD (73\%) dan yang berpendidikan SMP dan SMA(27\%), yang memiliki ketrampilan (10\%). Tingkat pendidikan kepala keluarga pada responden tergolong rendah hal ini menyebabkan mereka tidak kompetitif untuk masuk ke pekerja sektor industri di KEK, dimana sektor industri selain mensyaratkan tingkat pendidikan juga ketrampilan khusus sesuai industrinya. Adapun kepala keluarga yang memiliki ketrampilan yang menjadi responden pada penelitian ini adalah kepala keluarga yang memiliki ketrampilan pertukangan. Rumahtangga eks BHL yang kepala keluarganya memiliki ketrampilan pertukangan pada saat penelitian ini dari hasil wawancara relatif tidak mengalami tekanan dalam sistem penghidupan rumahtangganya, hal ini disebabkan dengan adanya walaupun tidak lagi sebagai BHL namundengan ketrampilan yang dimiliki dapat mengakses pekerjaan yang membutuhkan kertampilan pertukangan.

\section{Modal Fisik}

Sub komponen modal fisik yang dinilai adalah pemilikan aset dengan indikator kepemilikan kendaraan roda dua $(77 \%)$ dan memiliki rumah sendiri (80\%). Sub komponen menamfaatan aset indikatornya rumahtangga yang memanfaatkan rumahnya sebagai kontrakan (13\%) dan rumahtangga yang memanfaatkan kendaraan roda duanya sebagai ojek (20\%).Rumahtangga yang memanfaatkan rumahnya sebagai kontrakan dan kendaraan roda dua sebagai ojek dalam melayani pekerjapekerja di KEK adalah satu strategi 
penghidupan dengan memanfaatkan aset modal fisik yang dimilikinya.

\section{Modal Sosial}

Sub komponen modal sosial adalah jaringan sosial dengen kriteria suami dan istri penduduk asli desaSei Mangkei (37\%), suami atau istri merupakan penduduk luar desa (40\%) dan rumahtangga pendatang (7\%). Sub komponen jaringan sosial ini menjelaskan bahwa rumahtangga eks BHL pada penelitian ini masih memiliki jaringan sosial kekeluargaan dalam satu desa. Sedangkan sub komponen jaringan pengaman sosial dengan kriteria rumahtangga yang mengikuti arisan (73\%) hal ini dapat dijelaskan merujuk (Soembodo 2009)bahwa arisan merupakan tindakan-tindakan kolektif masyarakat kelas bawah dalam upaya meningkatkan kesejahteraannya, rumahtangga yang mendapat beras raskin (100\%), rumahtangga yang mengikuti program PNPM (13\%) program PMPN disini adalah program dana bergulir bagi usaha ibu-ibu rumahtangga. Rumahtangga yang mendapat program CSR maupun program kemitraan dari PTPN III (0\%), program CSR PTPN III di Kabupaten Simalungun saat penelitain ini dilakukan tidak ada yang dialokasikan untuk kegiatan pemberdayaan ekonomi masyarakat. Sedangkan program kemitraan dari PTPN IIImemberikan modal usaha kecil dengan bunga 6\% dengan masa pengembalian 36 bulan, sementara responden pada penelitian ini umumnya tidak memiliki usaha yang dapat menjadi mitra pada program tersebut.

\section{SIMPULAN}

Perubahan lanskap Afdeling I PTPN III dari perkebunan kelapa sawit menjadi Kawasan Ekonomi Khusus Sei Mangkei telah menjadi faktor yang menyebabkan ganguan sistem penghidupan rumahtangga eksBHL perkebunan kelapa sawitdi Desa Sei Mangkei. Penghidupan rumahtangga tersebut eks BHL dalam menggatasi gangguan sistem penghidupan tersebut pada penelitian ini memiliki kelentingan yang rendah. Rendahnya kelentingan tersebut dihubungkan dengan akses terhadap kepemilikan dan pemanfaatan modal-modal penghidupan yang dimilikinya.

\section{DAFTAR PUSTAKA}

Adger, WN. 2000. Social and ecological resilience: are they related?. Progress in Human Geography 24,3 pp. 347364

Belay, M., Abegaz, A., \& Bewket, W. (2017). Livelihood options of landless households and land contracts in north-west Ethiopia. Environment, Development and Sustainability, 19(1), 141-164.

Buhaerah, P., Puspita Sari, A., Nurjaman, R,. Augusta, C., [Kajian MP3EI Dalam Perspektif Hak Asasi Manusia]. Komisi Nasional Hak Asasi Manusia, Jakarta 2014.

Coordinating Ministry For Economic Affairs, Republic of Indonesia, Masterplan for Acceleration and Expansion of Indonesia Economic Development, 2011 http://www.kemlu.go.id/rome/Docum ents/MP3EI PDF.pdf (p. 46, 47 dan 53) 
Dai, DD., Ngan, LT,. Dien, NT,. 2013. Difficulties in Transition among Livelihoods under Agricultural Land Conversion for Industrialization: Perspective of Human Development. Mediterranean Journal of Social Sciences MCSER Publishing, RomeItaly. Vol 4 No 10 October 2013. DOI: $10.5901 / \mathrm{mjss} .2013 . v 4 \mathrm{n} 10 \mathrm{p} 259$

Ellis, F. (2000). The determinants of rural livelihood diversification in developing countries. Journal of Agricultural Economics, 51(2), 289302.

Etim, N. A. A., Akpan, A. U., \& Brown, U. A. (2013). Land and poverty: Some empirical findings using cross sectional data from Niger Delta Region, Nigeria. International Journal of Agricultural Management and Development, 3(3), 181-188.

Gil, Juliana DB,. 2017. The resilience of integrated agricultural systems to climate change." Wiley Interdisciplinary Reviews: Climate Change

Guarte, Jacqueline M., and Erniel B. Barrios. 2006. Estimation under purposive sampling. Communications in Statistics-Simulation and Computation 35.2 (2006): 277-284

Gunawan, G., \& Sugiyanto, S. (2017). Kondisi Sosial Ekonomi Keluarga Pasca Pemutusan Hubungan Kerja. Sosio Konsepsia, 16(1), 35-52.

Hahn, M. B., Riederer, A. M., \& Foster, S. 0. (2009). The Livelihood Vulnerability Index: A pragmatic approach to assessing risks from climate variability and change-A case study in Mozambique. Global Environmental Change, 19(1), 74-88
Holling, Crawford S,. 1973. Resilience and Stability Of Ecological Systems. Annual review of Ecology and Systematics 4.1

Laporan Akhir Tahun Dewan Nasional Kawasan Ekonomi Khusus, 2012 avialable on line http://kek.ekon.go.id/?wpdmdl=186 3 (diakses April 2017)

Panjaitan, N. K., Adriana, G., Virianita, R., Karlita, N., \& Cahyani, R. I. (2017). Adaptive capacity of coastal community to food insecurity due to climate change-a case of village in West Java. Sodality: Jurnal Sosiologi Pedesaan, 4(3).

Peterson, J. M., Caldas, M. M., Bergtold, J. S., Sturm, B. S., Graves, R. W., Earnhart, D., \& Brown, J. C. 2014. Economic linkages to changing landscapes. Environmental management, 53(1), 55-66.

Qasim, S., Qasim, M., Shrestha, R. P., Khan, A. N., Tun, K., \& Ashraf, M. (2016). Community resilience to flood hazards in Khyber Pukhthunkhwa province of Pakistan. International Journal of Disaster Risk Reduction, 18, 100-106

Saha, B., \& Bahal, R. (2016). Vulnerability Profile of Different Livelihood Groups in West Bengal. Indian Research Journal of Extension Education, 13(3), 75-81

Scoones,I,. 1998. Sustainable Rural Livelihoods A Framework For Analysis. IDS Working Paper, 72 . Brighton: IDS

Sullivan, C., 2002. Calculating a water poverty index. World Development 30 , 1195-1210 